\title{
Latissimus dorsi transposition for sequelae of obstetric palsy
}

\author{
EnRIQUe Vergara-Amador *
}

\section{SUMMARY}

Background: In obstetric palsy, limitation in the external abduction and rotation of the shoulder is the most frequent sequelae. Glenohumeral deformity is the result of muscular imbalance between the external and internal rotators. Releasing the contracted muscles and transferring the latissimus dorsi are the most common surgeries in this case.

Patients and methods: We operated on 24 children between 4 and 8 years of age with obstetric palsy sequelae to elevate the subscapularis muscle off the anterior surface of the scapula posteriorly and transfer the latissimus dorsi. The patients received a minimum of 2 years of follow up. They were evaluated based on Mallet's and Gilbert's classifications.

Results: All of the patients recovered within the above mentioned classifications. Out of 22 children evaluated via Mallet's classification, all improved from 3 to 4 on that scale. With respect to Gilbert's classification, 16 children improved one degree and 8 improved 2 degrees. All of the patients' parents were satisfied with the results.

Discussion: The benefit from releasing contracted muscles and muscle transfer to improve shoulder abduction in the sequelae of obstetric palsy has been amply reported in the literature. The results we had from elevating the subscapularis muscle off the anterior surface of the scapula and transferring the latissimus dorsi were good. Children who were difficult to classify based on the described scale were taken note of and some sub-classifications for Gilbert's descriptions were proposed. Patients must be selected carefully. To transfer the latissimus dorsi, it is necessary to have good passive mobility in abduction, a minimum of $20^{\circ}$ of external rotation and no joint deformities. When negative external rotation is found, the subscapularis muscle should be released. When there is glenohumeral joint deformity in older children, other methods are recommended, such as rotational humeral osteotomy.

Keywords: Obstetric palsy; Transfers muscular shoulder; Latissimus dorsi; Subscapular.

Transferencia del músculo dorsal ancho en secuelas obstétricas del plexo braquial

\section{RESUMEN}

Introducción: Las limitaciones en la abducción y la rotación externa del hombro son las secuelas más frecuentes en la parálisis obstétrica. Se encuentra deformidad de la articulación glenohumeral como resultado del desequilibrio que existe entre los músculos rotadores externos e internos. Dentro de las cirugías más usadas para corregir las deformidades del hombro están las liberaciones musculares y la transposición del músculo dorsal ancho.

Materiales y métodos: El autor operó 24 niños entre los 4 y 8 años de edad, con secuelas de parálisis braquial obstétrica, a quienes se les practicó liberación del subescapular por vía posterior y transferencia del músculo dorsal ancho. Se evaluaron según la escala de Mallet y la de Gilbert, con un seguimiento mínimo de dos años.

Resultados: Todos los niños se recuperaron según las escalas mencionadas. En 22 evaluados según Mallet, todos mejoraron del nivel 3 al 4 . Según la clasificación de Gilbert, 16 niños mejoraron un grado y 8 niños mejoraron dos grados. Todos los padres estuvieron satisfechos con los resultados.

Discusión: Existen muchos informes en la literatura médica sobre los beneficios de liberar los músculos contracturados y de las transferencias musculares en el hombro en las secuelas de parálisis braquial obstétrica. Se obtuvieron buenos resultados en todos los niños. Algunos casos fueron difíciles de clasificar en las escalas usadas, para lo cual se propone una sub-clasificación. Se requiere tener una buena movilidad pasiva, que no haya deformidad articular en el hombro y mínimo $20^{\circ}$ de rotación externa, para realizar la transferencia muscular del dorsal ancho. Cuando no se encuentra la rotación externa, se debe hacer la liberación del subescapular. Si hay deformidad de la articulación glenohumeral, no se recomiendan las

* Associate Professor, Hand surgeon and Pediatric orthopedist, Department of Orthopedics, Universidad Nacional de Colombia, Bogotá, DC, Colombia. Ancient resident, Institut Francais de la Main, Paris, France.

e-mail:emvergaraa@unal.edu.co

Received for publication July 23, 2009 Accepted for publication May 7, 2010 
transferencias musculares y entonces se recurre a osteotomías.

\section{Palabras clave: Parálisis braquial obstétrica; Transferencia muscular; Dorsal ancho.}

In obstetric brachial plexus injuries, most patients recover spontaneously without surgery. The nerve roots frequently compromised by typical Erb's palsy are C5 and C6, where an absence of abduction and external rotation of the shoulder, flexion of the elbow and supination of the forearm are found. When the $\mathrm{C} 7$ nerve root is affected, a deficit in the extension of the hand is generally found. Many of the total injuries at the beginning recovery of the lower roots and remain a definitely lesion of the upper plexus. Non-recovery of the bicep flexion against gravity before 3 to 4 months of age or of the deltoids has been an indication that plexus exploration is necessary ${ }^{1-3}$.

This indication has been extended to 6-9 months by different authors who have argued that nerve reconstruction procedures are useful up to the first year of age $^{4,5}$. Good functioning is expected for children who recover anti-gravity biceps strength before the age of 6 months. In the case of children whose biceps recover before the age of 6 weeks, it is possible to achieve total recovery ${ }^{6}$.

Limitation in abduction and external rotation caused by weakness in the deltoid muscles and the external rotators of the shoulder are the most frequent secondary deformities. Contracture in adduction and internal rotation could appear early due to the lack of opposition to the muscle forces generated by the subscapularis, pectoralis major, teres major and latissimus dorsi.

This difficulty in performing external rotation will produce posterior subluxation of the humeral head in the long term, causing it and the glenoid to become deformed. This will in turn bring about limitation in mobility and pain in the long run ${ }^{7,8}$. Early reconstruction, along with the release of the contracted tendons and tendinous transfers, will improve passive and active mobility and retard deformities in the glenohumeral joint ${ }^{9,10}$.

Releasing the compromised structures includes elevation of the subscapularis muscle. This can be done on the tendinous part of the muscle but it is not generally recommended because of the risk of residual instability. It can also be done through the posterior approach by releasing the muscle on the anterior surface of the scapula $^{5,11-13}$ and releasing the teres major and the pectoral major.

The transfer of the latissimus dorsi muscle is done to improve external rotation and the abduction at the same time. In 1934, L'Episcopo ${ }^{14}$ described the transfer of the latissimus dorsi and teres major to the lateral humerus to improve external rotation. Hoffer ${ }^{10}$ described the transfer of the latissimus dorsi by taking it posterior and superior in a rotator cuff to allow greater external rotation and abduction with a functional deltoid. When a good latissimus dorsi does not exist, transfers of the trapezium or of the scapula elevator may be considered ${ }^{12,15,16}$.

The purpose of this article is to describe the results in a case series with in the transfer of the latissimus dorsi with the elevation of the subscapularis muscle off the anterior surface of the scapula in children with obstetric palsy sequelae.

\section{PATIENTS AND METHODS}

There were 24 patients with obstetrical brachial plexus sequelae who had operations performed by the same surgeon (EVA), between 1997 and 2006, to transfer the latissimus dorsi, which, in the cases of 11 children, was associated with elevation of the subscapularis muscle. There was a minimum follow up of 2 years. Movement of the shoulder was limited in all cases, especially in abduction and external rotation, which made it difficult to carry out some ordinary daily activities like getting dressed, combing the hair, and lifting objects to the face or mouth. Six patients had an operation on the plexus before they were one year of age and 18 had not received any surgical treatment.

A transfer of the latissimus dorsi to the infraspinous and supraspinous tendon was done on all of the patients. Releasing the subscapularis muscle was done at the same time on 11 patients except for one who had been operated on at 3 years of age to elevate just the subscapularis muscle. The criteria for releasing the subscapularis muscle was external passive rotation of less than $20^{\circ}$. All the patients had normal morphology in the X-rays. When there was a poor image on the X-ray, a CT scan was taken. The average age at the time of surgery was 5.1 years of age (ranging from 4 to 8 years of age). The minimum age for surgery was 4 ; patients were evaluated before and after the operation based on 
Table 1

Mallet's scale

\begin{tabular}{llll}
\hline Stage & Abduction & External rotation & \multicolumn{1}{c}{ Hand } \\
\hline 1 & Flaccid shoulder & Flaccid shoulder & $\begin{array}{l}\text { Flaccid shoulder } \\
\text { The hand does not reach the back of the neck } \\
\text { or the back and the hand reaches the mouth } \\
\text { in a horn borner sign } \\
\text { The hand reaches the back of the neck and } \\
\text { back with difficulty, the hand reaches the } \\
\text { mouth with a partial horn borner sign. }\end{array}$ \\
\hline 4 & between $30^{\circ}$ and $90^{\circ}-20^{\circ}$ & $\begin{array}{l}\text { The hand reaches the back of the neck, the } \\
\text { back and mouth easily. } \\
\text { Normal shoulder }\end{array}$ \\
\hline
\end{tabular}

Table 2

Shoulder scale (Gilbert)

\begin{tabular}{cll}
\hline Stage & Abduction & \multicolumn{1}{c}{ External rotation } \\
\hline 0 & $\begin{array}{l}\text { Complete } \\
\text { paralysis } \\
\leq 45^{\circ}\end{array}$ & $\begin{array}{l}\text { Complete paralysis } \\
\text { Negative external } \\
\text { rotation }\end{array}$ \\
2 & $<90^{\circ}$ & $\begin{array}{l}\text { Negative external } \\
\text { rotation }\end{array}$ \\
3 & $90^{\circ}$ & $\begin{array}{l}\text { Slight external rotation } \\
\text { Incomplete external } \\
\text { rotation }\end{array}$ \\
5 & $<120^{\circ}$ & Active external rotation \\
\hline
\end{tabular}

Mallet's scale and the scale for the shoulder described by Gilbert (Tables 1,2).

Surgical technique. The patient is placed in lateral decubitus position under general anesthesia. An approximately $5 \mathrm{~cm}$ axial incision is made on the lateral border of the scapula when a release of the scapula is being planned. When only a transfer is planned, the incision is made in the posterior axillary fold; it is dissected subcutaneously and the interval of the latissimus dorsi with the teres major is located on the external border of the scapula. If the latissimus dorsi is of poor quality, the teres major will be added to the transfer. Because the teres major is smaller with a lesser excursion than the latissimus dorsi, the teres major is released from the latissimus dorsi and sutured to the same muscle more proximally, thus, integrating the two muscles to the transfer. The dissection towards the humerus is performed with extreme care. It is not necessary to see the radial nerve. This last part can be done with blunt dissection up to the insertion of the latissimus dorsi into the humerus. The muscle is released and lifted while being careful not to exert tension on the vascular-nervous pedicle. With the latissimus dorsi lifted, we reach the lateral border of the scapula and the subscapularis muscle is lifted subperiosteally, starting on the lateral and inferior border and continuing towards the medial and superior border with a periosteal elevator. It is important to release the medial corners because, if not, the subscapularis muscle cannot slide well. After that, the shoulder should rotate $30^{\circ}$ externally. If it is not possible to achieve good external rotation at the moment, consider releasing the anterior capsule of the shoulder and of the coracohumeral ligament (CHL) without cutting the subscapularis muscle tendon.

The latissimus dorsi tendon goes under the deltoids and it is sutured to the infraspinous on the lateral superior part. A fast anchor was not used in any case. If abduction improvement is rendered, the latissimus dorsi is sutured to the supraspinatus tendon with the arm at maximum external rotation and an abduction of 90 to $120^{\circ}$. The wound is closed in two layers with absorbable suture. The arm is immobilized in a position of minimal abduction of $90^{\circ}$ degrees and with external rotation in the Statue of Liberty position for 5 weeks. When rehabilitation is started, immobilization is continued at night for three more weeks. 


\section{RESULTS}

Overall, we obtained good results; there were no hematomas, neurological or vascular injuries, nor infection. Of 22 patients scored on Mallet's functional scale, all were at 3 points before surgery and improved to 4 points. Based on Gilbert's scale, 13 patients were at 3 before surgery and improved to 4 . Seven patients were at 2 and improved to 4 . One patient was at an intermediate classification between 2 and 3 and improved to 4 . One patient went from 3 to 5 , and two patients went from 4 to 5. In other words, all of the patients improved in the two scales (Figures 1, 2; Table 3). The parents of the patients were satisfied with the functional results (Figures 3,4).

\section{DISCUSSION}

External rotation and abduction of the shoulder with progressive contracture in internal rotation and adduction are the most important sequelae for the shoulder in obstetric paralysis. The muscular imbalance between the weak external rotator (infraspinous) and the strong internal rotators (teres major, latissimus dorsi, pectoral

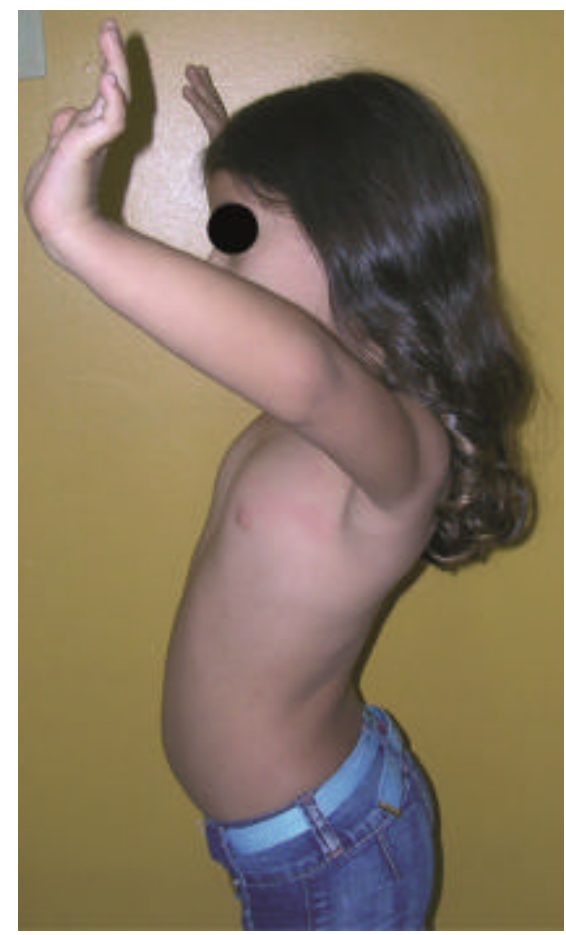

Figure 1. Four-and-a-half-year old girl; obstetric palsy sequelae with a limitation in abduction $\left(9^{\circ}\right)$

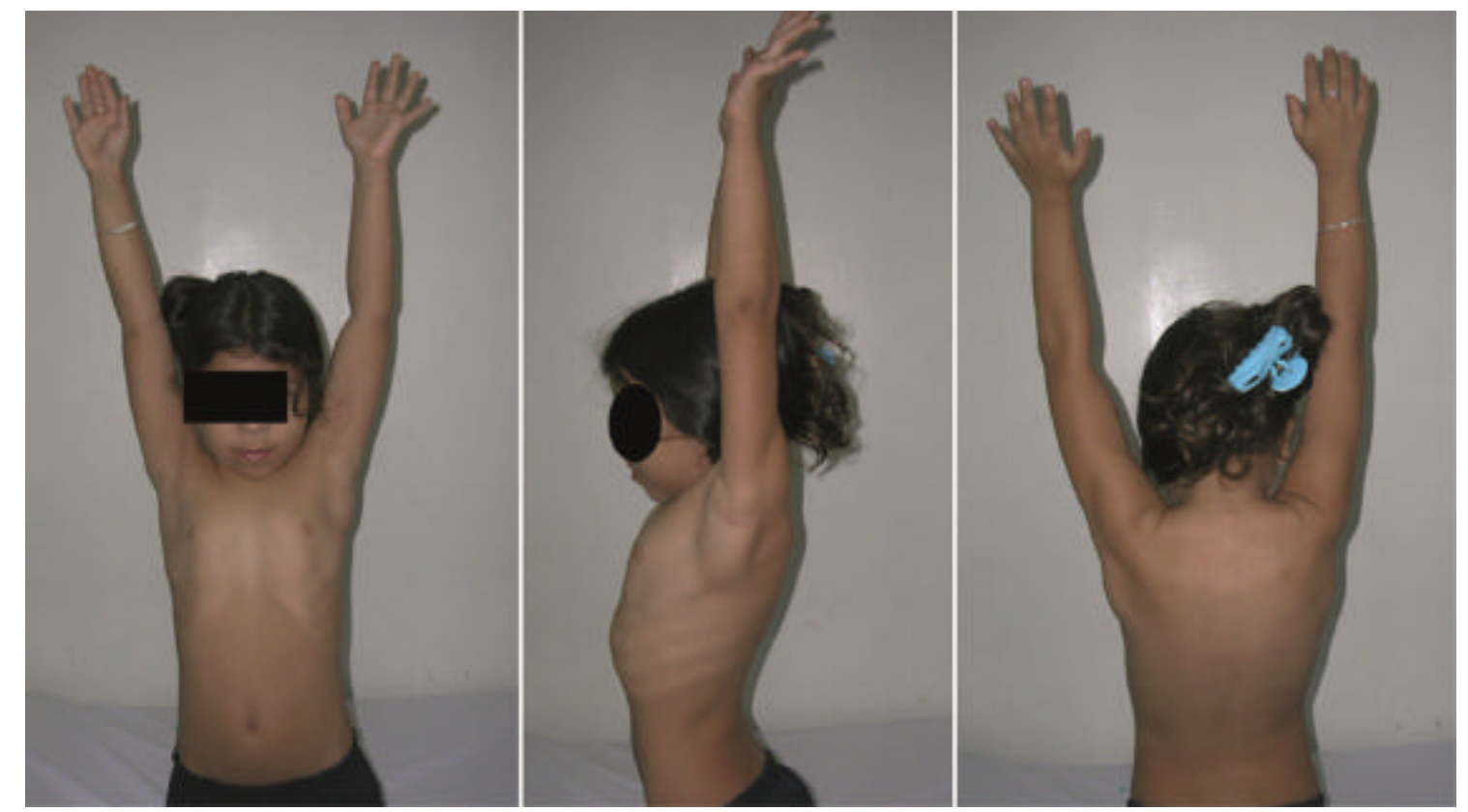

Figure 2. Eighteen months post operative. After releasing the subscapularis muscle and latissimus dorsi transfer, the abduction is greater than $120^{\circ}$ and external rotation is greater than $20^{\circ}$. (Mallet 4-5, Gilbert 5) 
Table 3

Results of transfer of the latissimus dorsi according to the Gilbert's scale and Mallet's functional scale

\begin{tabular}{|c|c|c|c|c|c|c|c|}
\hline \multirow[t]{2}{*}{ Case } & \multirow[t]{2}{*}{ Lesion } & \multirow[t]{2}{*}{ Age } & \multirow[t]{2}{*}{ Technique } & \multicolumn{2}{|c|}{ Mallet } & \multicolumn{2}{|c|}{ Gilbert } \\
\hline & & & & pre & post & pre & post \\
\hline 1 & $\mathrm{C} 5-\mathrm{C} 6 \mathrm{C} 7$ & 5 & Latissimus dorsi & 3 & 4 & 2 & $4-5$ \\
\hline 2 & C5-C6 & 4 & Latissimus dorsi & 3 & 4 & 2 & 4 \\
\hline 3 & C5-C6 & 7 & Subesc+Latissimus & 3 & 4 & 2 & 4 \\
\hline 4 & C5-C6 & 5 & Subesc+Latissimus & 3 & 4 & $2-3$ & 5 \\
\hline 5 & C5-C6 & 5 & Latissimus dorsi & 3 & 4 & 2 & 4 \\
\hline 6 & $\mathrm{C} 5-\mathrm{C} 6 \mathrm{C7}$ & 4 & Latissimus dorsi & 3 & 4 & 3 & 4 \\
\hline 7 & $\mathrm{C} 5-\mathrm{C} 6 \mathrm{C} 7$ & 8 & Subesc+Latissimus & 3 & 4 & 3 & 4 \\
\hline 8 & $\mathrm{C} 5-\mathrm{C} 6 \mathrm{C} 7$ & 6 & Latissimus dorsi & 3 & 4 & 3 & 4 \\
\hline 9 & C5-C6 & 5 & Latissimus dorsi & 3 & 4 & 3 & 4 \\
\hline 10 & C5-C6 & 5 & Subesc+Latissimus & 3 & 4 & 2 & 4 \\
\hline 11 & $\mathrm{C} 5-\mathrm{C} 6 \mathrm{C7}$ & 4 & Subesc+Latissimus & 3 & 4 & 3 & 4 \\
\hline 12 & C5-C6 & 5 & Latissimus dorsi & 3 & 4 & $2-3$ & 4 \\
\hline 13 & C5-C6 & 5 & Latissimus dorsi & 3 & 4 & 3 & 4 \\
\hline 14 & $\mathrm{C} 5-\mathrm{C} 6 \mathrm{C} 7$ & 6 & Latissimus dorsi & 3 & 4 & 3 & 4 \\
\hline 15 & C5-C6 & 6 & Subesc+Latissimus & & & 4 & 5 \\
\hline 16 & C5-C6 & 7 & Subesc+Latissimus & & & 4 & 5 \\
\hline 17 & C5-C6 & 4 & Subesc+Latissimus & 3 & 4 & 3 & 4 \\
\hline 18 & C5-C6 & 5 & Subesc+Latissimus & 3 & 4 & 3 & 4 \\
\hline 19 & C5-C6 & 5 & Latissimus dorsi & 3 & 4 & 2 & 4 \\
\hline 20 & C5-C6C7 & 4 & Latissimus dorsi & 3 & 4 & 3 & 4 \\
\hline 21 & C5-C6C7 & 4 & Latissimus dorsi & 3 & 4 & 3 & 4 \\
\hline 22 & $\mathrm{C} 5-\mathrm{C} 6 \mathrm{C7}$ & 5 & Subesc+Latissimus & 3 & 4 & 3 & 4 \\
\hline 23 & C5-C6 & 5 & Latissimus dorsi & 3 & 4 & 2 & 4 \\
\hline 24 & $\mathrm{C5} 5-\mathrm{C} 6 \mathrm{C} 7$ & 5 & Subesc+Latissimus & 3 & 4 & 3 & 4 \\
\hline
\end{tabular}

major, and subscapularis) is the main factor for deformity in internal rotation and adduction of the shoulder.

The subscapularis is the largest of the four rotator cuff muscles. Einarsson et al. ${ }^{17}$, demonstrated the abnormal mechanical properties of the subscapularis muscle in individuals with obstetric brachial plexus palsy when they analyzed the passive mechanical characteristics of biopsies from the subscapularis muscle obtained through open surgery.

Secondary deformities such as the elongation of the coracoids, flattening or deformation of the humeral head with subluxation or posterior dislocation and flattening or retroversion of the glenoid may be found ${ }^{7,8}$.

Hoeksma et al. ${ }^{7}$, reported a $56 \%$ prevalence of contractures greater than $10 \%$ and a $33 \%$ prevalence of osseous deformity in a series of 53 patients treated without surgery. Waters et al. ${ }^{9}$, say that the natural history of obstetrical brachial paralysis with muscular weakness is glenohumeral deformity because of muscular imbalance. Using computed tomography (CT) or magnetic resonance imaging (MRI) to evaluate the gleno scapular angle (retroversion) on a series of 42 patients, the healthy side showed -5.5 on the average and the affected side, -25.7 with $62 \%$ of the patients presenting posterior subluxation and increased deformity with age.

Bahm et al. ${ }^{18}$, noted that although the muscular imbalance might explain most of the progressing deformities of the glenohumeral joint, it was necessary to be aware of the rare cases of connatal traumatic 
subluxations of the humeral head, which can cause a rapid contracture requiring immediate surgery.

The anterior release of the subscapularis muscle has been used extensively but has the drawback of causing anterior instability in the shoulder. Carlioz and Brahimi ${ }^{11}$ improved the external rotation of the shoulder by releasing the subscapularis muscle off the anterior surface of the scapula through a posterior approach. This is indicated when the patient still has a congruent glenohumeral joint ${ }^{13,19}$. If the external rotator muscles are weak, transfer of the latissimus dorsi should be done immediately, as well. This transfer will improve active abduction of the shoulder given that it stabilizes the rotator cuff and makes the deltoids more effective ${ }^{13,16}$.

Pagnotta et al. ${ }^{13}$, evaluated 203 patients who had undergone operations on their shoulders followed by long-term follow up. This showed that individuals benefiting most from the surgery were children who had C5 and C6 paralysis and those who scored 2 and 3 on the Gilbert scale. According to the authors, six years after the surgery some patients presented loss of abduction but kept external rotation. It is possible that the cause of this is functional exclusion on the part of the child and lack of rehabilitation.

All of the children in this report improved in abduction and external rotation. Our follow up is relatively short and loss of abduction has not been observed. All of the children improved on the functional scales. The 22 who were evaluated based on Mallet's scale improved one degree. Eight patients improved two degrees and 16 patients improved one degree based on Gilbert's scale. Two children could not be correctly classified on Mallet's scale prior to surgery. They had more than $90^{\circ}$ of
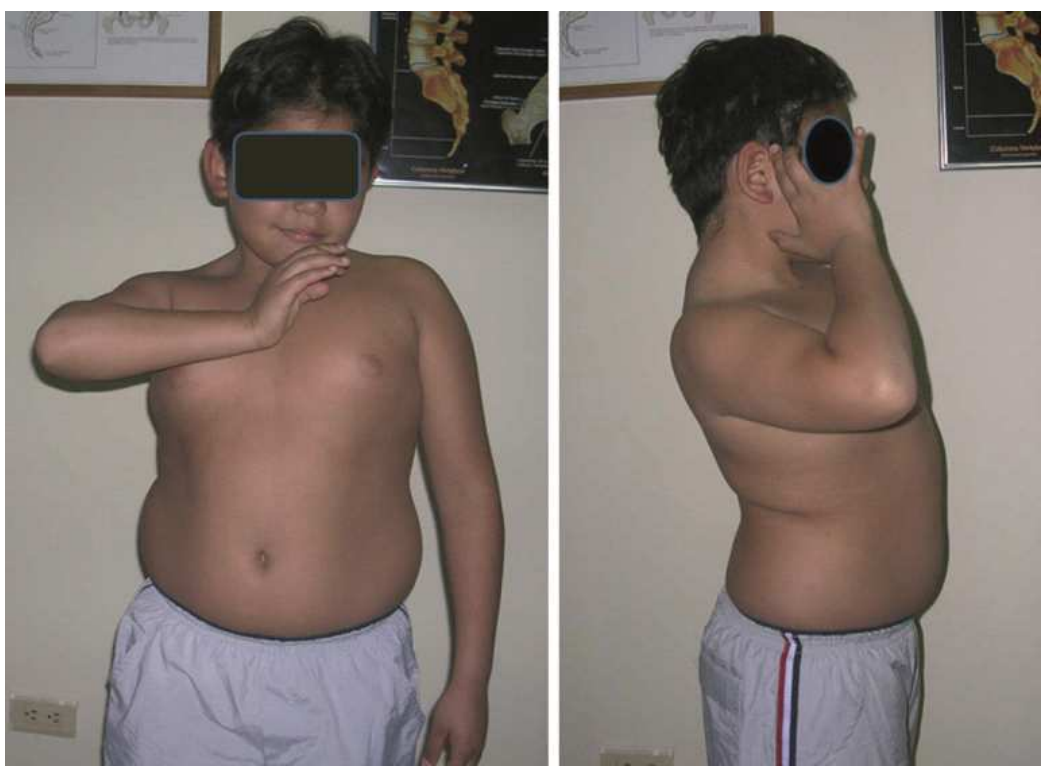

Figure 3. Eight-year old boy; obstetric palsy sequelae with limitation in abduction $\left(90^{\circ}\right)$ and external rotation $\left(0^{\circ}\right)$
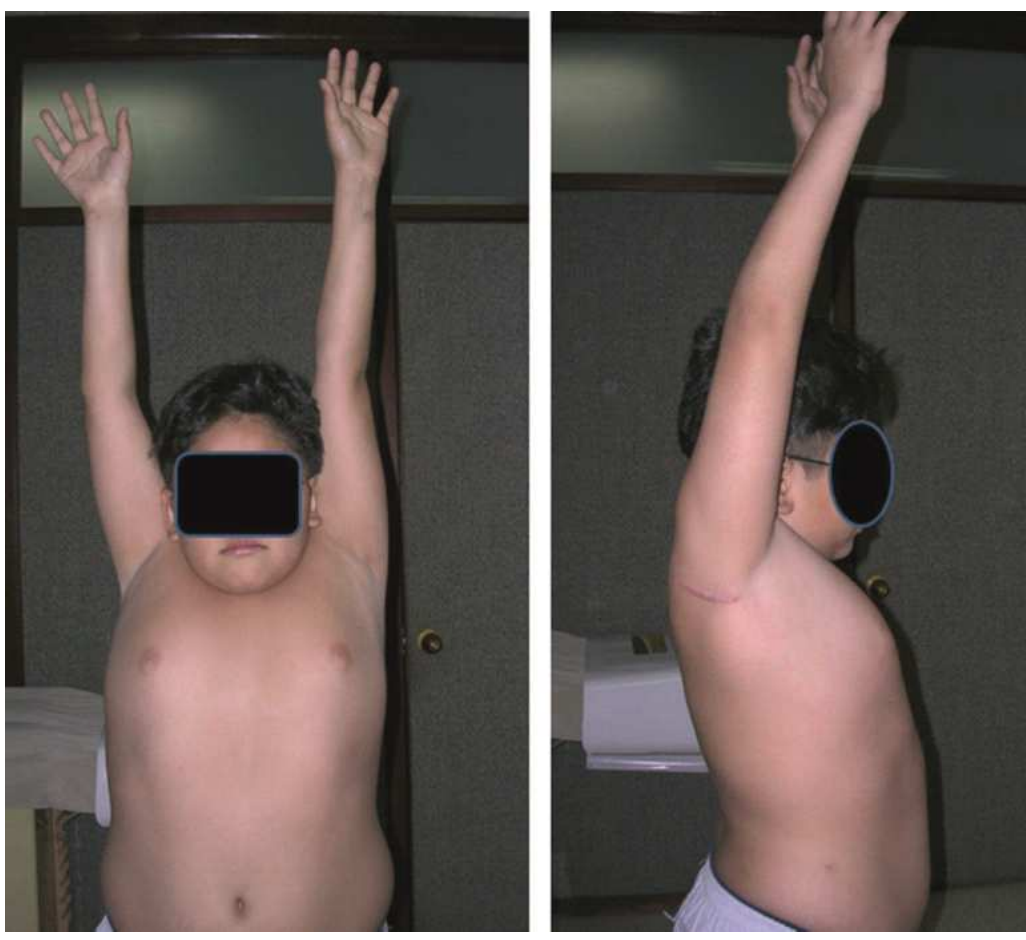

Figure 4. Twenty months post operative. Good result after releasing the subscapularis muscle and latissimus dorsi transfer; abduction is greater than $120^{\circ}$ and external rotation is greater than $20^{\circ}$

abduction but a deficit of external rotation of $0^{\circ}$ and $-20^{\circ}$.

We noticed patients who were not easily classified. There were children who were found between Mallet's classifications of 3 and 4. 
There were patients whose degrees of abduction were greater than $90^{\circ}$, but whose external rotations were less than $20^{\circ}$ or negative, making it impossible to classify them. Gilbert's classification gives us a closer approach to reality than Mallet's, although there are some patients whose recovery of abduction and external rotation are dissociated. For example, case 16 presented abduction greater than $120^{\circ}$, but an external rotation of $0^{\circ}$.

Currently, patients who are classified into stages 3 , 4 , and 5 on Gilbert's scale are being evaluated and subclassified. The breakdown we used for this subclassification is the following:

- 3A: abduction of $90^{\circ}$ and external rotation of $0^{\circ}$ or negative

- 3B: abduction of $90^{\circ}$ and slight or positive external rotation

- 4A: abduction of less than $120^{\circ}$ and external rotation of $0^{\circ}$ or negative

- 4B: abduction of less than $120^{\circ}$ and positive or incomplete external rotation

- 5A: abduction greater than $120^{\circ}$ and external rotation less than $20^{\circ}$

- 5B: abduction greater than $120^{\circ}$ and external rotation greater than $20^{\circ}$

The patients have to be carefully selected. Good passive mobility in abduction, a minimum external rotation of $20^{\circ}$ and no joint deformities are required for the transfer of the latissimus dorsi. When an external rotation of $0^{\circ}$ or negative is found, releasing the subscapularis muscle is considered. At the same time, we evaluated whether or not it was necessary to release the major pectoral muscle. Sometimes, though not in this series, it is necessary to release the anterior capsule of the glenohumeral joint through an anterior approach or the coracohumeral ligament.

When there is posterior subluxation or glenohumeral joint deformity in older children, other methods are recommended such as rotational osteotomy of the proximal humerus. ${ }^{20}$

No benefits in any form have been received or will be received from any commercial party related directly or indirectly to the subject of this article.

\section{REFERENCES}

1. Gilbert A, Tassin JL. Surgical repair of the brachial plexus in obstetric paralysis. Chirurgie. 1984; 110: 70-5.
2. Waters PM. Comparison of the natural history, the outcome of microsurgical repair and the outcome of operative reconstruction in brachial plexus birth palsy. J Bone Joint Surg Am. 1999; 81-A: 649-59.

3. Birch R, Ahad N, Kono H, Smith S. Repair of obstetric brachial plexus palsy: results in 100 children. J Bone Joint Surg (Br). 2005; 87-B: 1089-95.

4. Clarke HM, Curtis C. Examination and prognosis. In: Gilbert A (ed.). Brachial plexus injuries. London: Martin Dunitz in association with the Federation of European Societies for Surgery of the Hand; 2001. p. 159-72.

5. Haerle M, Gilbert A. Management of complete obstetric brachial plexus lesions. J Pediatr Orthop. 2004; 24: 194-200.

6. Waters PM. Update on management of pediatric brachial plexus palsy. J Pediatr Orthop B. 2005; 14: 233-44.

7. Hoeksma AF, Ter Steeg AM, Dijkstra P, Nelissen RG, Beelen A, Jong BA. Shoulder contracture and osseous deformity in obstetrical brachial plexus injuries. J Bone Joint Surg Am. 2003; 85-A: 316-22.

8. Birch, R. Medial rotation contracture, posterior dislocation of the shoulder. In: Gilbert A (ed.). Brachial plexus injuries. London: Martin Dunitz in association with the Federation of European Societies for Surgery of the Hand; 2001. p. 249-59.

9. Waters PM, Bae DS. Effect of tendon transfers and extraarticular soft-tissue balancing on glenohumeral development in brachial plexus birth palsy. J Bone Joint Surg. 2005; 87-A: 320-5.

10. Hoffer M, Wickenden R, Roper B. Brachial plexus birth palsies. Results of tendon transfers to the rotator cuff. $J$ Bone Joint Surg. 1978; 60-A: 691-5.

11. Carlioz H, Brahimi L. La place de la désinsertion interne du sous-scapulaire dans la traitement de la paralysie obstétricale du membre supérieur chez l'enfant. Ann Chir Infantile. 1971; 12: $159-67$.

12. Raimondi PL, Muse A, Saporiti E. Palliative surgery: shoulder paralysis. In: Gilbert A (ed.). Brachial plexus injuries. London: Martin Dunitz in association with the Federation of European Societies for Surgery of the Hand; 2001. p. 225-38.

13. Pagnotta A, Haerle M, Gilbert A. Long-term results on abduction and external rotation of the shoulder after latissimus dorsi transfer for sequelae of obstetric palsy. Clin Orthop Relat Res. 2004; 426: 199-205.

14. Strecker WB, McAllister JW, Manske PR, SchoeneckerPL, Dailey LA. Sever-L'Episcopo transfers in obstetrical palsy: a retrospective review of twenty cases. J Pediatr Orthop. 1990; 10: 442-4.

15. Chen L, Gu YD, Hu SN. Applying transfer of trapezius and/ or latissimus dorsi with teres major for reconstruction of abduction and external rotation of the shoulder in obstetrical brachial plexus palsy. J Reconstr Microsurg. 2002; 18: 275-80.

16. Van Kooten EO, Fortuin S, Winters HA, Ritt MJ, Van der Sluijs HA. Results of latissimus dorsi transfer in obstetrical brachial plexus injury. Tech Hand Up Extrem Surg. 2008; 12: 195-9.

17. Einarsson F, Hultgren T, Ljung BO, Runesson E, Fridén J. Subescapularis muscle mechanics in children with obstetric brachial plexus palsy. J Hand Surg Eur. 2008; 33: 507-12.

18. Bahm J, Wein B, Alhares G, Dogan C, Radermacher K, Schuind F. Assessment and treatment of glenohumeral joint deformities 


\section{Colombia Médica}

in children suffering from upper obstetric brachial plexus palsy. J Pediatr Orthop (Br). 2007; 16: 243-51.

19. Gilbert A. Long-term evaluation of brachial plexus surgery in obstetrical palsy. Hand Clin. 1995; 11: 583-95.
Vol. 41 № 3, 2010 (Julio-Septiembre)

20. Kirkos JM, Papadopoulos IA. Late treatment of brachial plexus palsy secondary to birth injuries: rotational osteotomy of the proximal part of the humerus. J Bone Joint Surg. 1998; 80-A: $1477-83$ 